\title{
Age-based immunomorphological analysis of rat testis in streptozotocin-induced diabetes mellitus
}

\author{
I.-A. V. Kondrat ${ }^{1, B, D}$, I. S. Shponka ${ }^{2, A, F}$, T. V. Shynkarenko ${ }^{\mathbb{D}}$ *2,B,C,D,E
}

${ }^{1}$ Ivano-Frankivsk National Medical University, Ukraine, ${ }^{2}$ Dnipro State Medical University, Ukraine

A - research concept and design; B - collection and/or assembly of data; C - data analysis and interpretation; D - writing the article;

$\mathrm{E}$ - critical revision of the article; $\mathrm{F}$ - final approval of the article

Key words: diabetes mellitus, testis, immunohistochemistry, rat, age factor.

Pathologia 2021; 18 (1), 12-18

*E-mail: timash3061990@ gmail.com
Diabetes mellitus (DM) has emerged as a public healthcare problem. Sustained hyperglycemia has been linked with many complications including impaired male fertility.

The aim of the study: to evaluate the effect of STZ-induced diabetes mellitus on testicular immunomorphology both in the peripubertal period and adulthood of rats.

Material and methods. Peripubertal male rats were injected with STZ $(70 \mathrm{mg} / \mathrm{kg})$, adult rats received $60 \mathrm{mg} / \mathrm{kg}$. Immunohistochemical staining was performed to assess cell proliferation (Ki-67), apoptosis (caspase-3), expression of androgen receptors (AR), Wilms Tumor (WT1) protein. Also, the morphology of blood vessels was analyzed on the basis of CD34-immunoreactivity. Taking into consideration the small groups of animals, statistical analysis was made with the Mann-Whitney $U$ test.

Results. Fewer rows of proliferating spermatogonia were observed in the experimental animals $(P<0.05)$ of both age groups. Surprisingly, diabetes resulted in decreased caspase-3 expression $(P<0.05)$ except for the early period $(2$ weeks) in the peripubertal group, in which this trend was not observed. The same principles are true in terms of AR expression in seminiferous tubules. Hyperglycemia prevented immature testes from the complete development but thickens the walls of microvessels $(P<0.05)$. Also, the atrophy of spermatogenic epithelium and Sertoli cells was registered in most tubules of all the experimental groups $(P<0.05)$.

Conclusion. the diabetic injury of testicular tissue is a long time process possessing characteristic feature in the peripubertal period, for example, the later development of AR deficiency. In addition, the high level of apoptosis is characteristic of an immature testis and so is the tendency of caspase-immunoreactivity to persist.
Киючові слова: цукровий Аіабет, яєчка, імуногістохімія, щур, віковий фактор.

Патологія. 2021

T. 18, № 1(51).

C. $12-18$

\section{Імуноморфологічний аналіз яєчок щурів зі стрептозотоцин-індукованим цукровим діабетом: віковий аспект}

\section{І.-А. В. Кондрат, І. С. Шпонька, Т. В. Шинкаренко}

Цукровий діабет (ЦД) - суттєва проблема системи охорони здоров'я. Тривала гіперглікемія пов'язана з багатьма ускладненнями, включаючи порушення фертильності чоловіків.

Мета роботи - оцінити вплив індукованого стрептозотоцином (STZ) цукрового діабету на імуноморфологію яєчок щурів у перипубертатному періоді та дорослому віці.

Матеріали та методи. Перипубертатним самцям щурів уводили STZ у дозі 70 мг/кг, дорослі щури отримували 60 мг/кг. Імуногістохімічні реакції проводили для оцінювання проліферації клітин (Ki-67), апоптозу (caspase-3), експресії рецепторів андрогенів (AR), білка пухлини Вільмса (WT1). Також аналізували морфологію судин на основі CD34-імунореактивності. Враховуючи невеликі групи тварин, статистичний аналіз здійснили за допомогою тесту Манна-Вітні.

Результати. В експериментальних тварин $(p<0,05)$ обох вікових груп спостерігали менше рядків сперматогоній, що мітотично діляться. Дивно, але діабет призвів до зниження експресії каспази-3 ( $p<0,05)$, за винятком раннього періоду (2 тижні) у групі перипубертату, в якій цей тренд не зафіксований. Подібні закономірності виявлені для експресії рецепторів андрогенів. Гіперглікемія запобігла повноцінному розвитку незрілих яєчок, але потовщила стінки мікросудин ( $p<0,05)$. Також зареєстровано атрофрію сперматогенного епітелію та клітин Сертолі в більшості канальців у всіх експериментальних групах.

Висновки. Діабетичне пошкодження тканин яєчок - тривалий процес, що має характерні особливості в перипубертатному періоді, наприклад пізніший дефріцит AR. Крім того, високий рівень апоптозу характерний для незрілого яєчка, як і тенденція до збереження caspase3-імунореактивності.

Ключевые слова: сахарный Аиабет, яички, иммуногистохимия, крыса, возрастной фактор.

Патология. 2021. T. 18, № 1(51). C. 12-18

\section{Иммуноморфологический анализ яичек крыс со стрептозотоцин-индуцированным сахарным диабетом: возрастной аспект}

\section{И.-А. В. Конарат, И. С. Шпонька, Т. В. Шинкаренко}

Сахарный диабет (СД) стал значительной проблемой здравоохранения. Длительная гипергликемия связана со многими осложнениями, включая нарушения фертильности мужчин.

Цель работы - оценить влияние индуцированного стрептозотоцином (STZ) сахарного диабета на иммуноморфологию яичек крыс в перипубертатном периоде и взрослом возрасте. 
Материалы и методы. Перипубертатным самцам крыс вводили STZ в дозе 70 мг/кг, взрослые крысы получали 60 мг/кг. Иммуногистохимические реакции проводили для оценки пролиферации клеток (Ki-67), апоптоза (caspase-3), экспрессии рецепторов андрогенов (AR), белка опухоли Вильмса (WT1). Также анализировали морфологию сосудов на основе CD34-иммунореактивности. Учитывая небольшие группы животных, статистический анализ провели с помощью теста Манна-Уитни.

Результаты. У экспериментальных животных обеих возрастных групп отмечено меньше рядов митотически делящихся сперматогоний ( $<$ < 0,05). Удивительно, но диабет привел к снижению экспрессии каспазы-3 ( $<$ < 0,05) за исключением раннего периода (2 недели) в группе перипубертата, в которой этот тренд не зафиксирован. Подобные закономерности обнаружены для экспрессии рецепторов андрогенов. Гипергликемия предотвратила полноценное развитие незрелых яичек, но стенки микрососудов стали толще ( $<$ < 0,05). Также зарегистрировали атрофию сперматогенного эпителия и клеток Сертоли в большинстве канальцев во всех экспериментальных группах.

Выводы. Диабетическое повреждение тканей яичек - длительный процесс, имеющий характерные особенности в перипубертатном периоде, например дефицит AR развивается впоследствии. Кроме того, высокий уровень апоптоза характерен для незрелого яичка, как и тенденция к сохранению caspase3-иммунореактивности.

Diabetes mellitus is considered to be a quite common cause of infertility worldwide. Unfortunately, this complication is observed in both diabetes mellitus type 1 and type 2. In the latter case, however, the increased aromatization and circulating estrogens resulting in $\mathrm{LH}$ inhibition as well as obstructive sleep apnea syndrome (with direct hypoxemic effect and indirect via the hypothalamic-pituitary-gonadal axis) are main contributors to the secondary (hypogonadotropic) hypogonadism [1]. Nevertheless, the hyperglycemic state promotes behavioral, structural, and molecular changes by itself as shown in numerous previous publications on alloxan- and streptozotocin-induced diabetes in rodents $[2,3]$.

Both reactive oxygen and nitrogen species are known to be responsible for the modification of intracellular biomolecules, such as lipids, proteins, nucleic acids, and carbohydrates, in induced hyperglycemia.

Kanter et al. reported a reduction in the diameters of seminiferous tubules and spermatogenic cells and damage to the morphology of the epithelium in diabetic rats $[4,5]$.

However, there are no scientific papers on the influence of diabetes on testicular immunomorphology in the peripubertal period. Indeed, little is known about the expression of essential genes in testicular tissue.

Although big effort has been made for controlling blood glucose, the complication of diabetes is still the major reason to cause organ dysfunction and death.

\section{Aim}

The aim of the study was to evaluate the effect of STZ-induced diabetes mellitus on testicular immunomorphology both in the peripubertal period and adulthood of rats.

\section{Materials and methods}

Animals. The study was carried out on 48 white outbred peripubertal (2-month-old) and 48 sexually mature (12-month-old) male rats (Table 1) that were acclimatized to the experimental conditions for at least 1 week prior to the start of the experiment in Ivano-Frankivsk National Medical University. They consumed a standard laboratory diet and water according to the policy of free access.

Ethical issues. The study was approved by the Ethical Committee of Ivano-Frankivsk National Medical University, Ivano-Frankivsk, Ukraine (conclusion № 109/19).
All the procedures were carried out in accordance with the guidelines of the EU Directive 2010/63/EU for animal experiments.

Induction of DM. The rats were divided into 2 groups: control and experimental. In the experimental group, diabetes was induced by a single intraperitoneal injection of streptozotocin (SIGMA, USA) $7 \mathrm{mg} / 100 \mathrm{~g}$ body weight in immature animals and $6 \mathrm{mg} / 100 \mathrm{~g}$ body weight in adult animals (dissolved in $0.1 \mathrm{M}$ citrate buffer solution with $\mathrm{pH}=4.5$ ). In order to avoid hypoglycemia (because of the destruction of $\beta$-cells), they received additional glucose for one day. In the control group of animals, the equal volume of $0.1 \mathrm{M}$ citrate buffer was injected intraperitoneally.

Four days later, a blood sample was collected from the tail vein, and hyperglycemia was confirmed by a blood glucose level ( $\geq 13 \mathrm{mmol} / \mathrm{L})$. Glucose was determined using a commercial glucometer (ACCU-CHEK® Active, Roche Diagnostics, Germany)

Microscopic analysis. All the rats were sacrificed by means of decapitation two weeks (for the evaluation of short-term effects) or ten weeks (long-term effects) after the injections. For light microscopic observation, the testes samples were fixed in $10 \%$ buffered formaldehyde, dehydrated in ethanol, and embedded in paraffin. Then, the blocks were sent to the Department of Pathological Anatomy and Forensic Medicine (Dnipro State Medical University), where the following steps were done.

The testes tissues were cut into $4-\mu \mathrm{m}$-thick sections. The sections were then deparaffinized with xylene and rehydrated with alcohol and water. The rehydrated sections were stained with hematoxylin and eosin

Immunohistochemistry. Besides the routine histological examination (hematoxylin-eosin staining), the immunohistochemical analysis was performed according to the TermoScientific (TS) protocols with primary antibodies: rabbit anti-Ki-67 (1:400; Abcam, Cambridge, MA, USA), mouse anti-caspase3 (1:100; TS, CA, USA), mouse anti-WT1 (1:100; Diagnostic BioSystems, CA, USA), rabbit anti-AR (1:200; TS, USA), rabbit anti-CD34 (1:100; TS, CA, USA). Visualization system Lab Vision Quanto (TS, USA) was used with the detection of the protein chain using DAB Quanto Chromogen (TS, USA) for $4 \mu \mathrm{m}$ thick cut-offs. A negative control slide was prepared from one specimen using a non-immune solution instead of the primary antibodies. 
Table 1. Groups of rats according to the age and the duration of hyperglycemia (time after the injection)

\begin{tabular}{|c|c|c|c|c|}
\hline \multirow[t]{2}{*}{ Time after the injection, days } & \multicolumn{2}{|c|}{ 2-month-old peripubertal rats (weighing 65-95 g), n } & \multicolumn{2}{|c|}{ 12-month-old mature rats (weighing $160-180 \mathrm{~g}$ ), $\mathrm{n}$} \\
\hline & Peripubertal I (control) & Peripubertal II (experiment) & Adult I (control) & Adult II (experiment) \\
\hline 14 (short-term effects) & 9 & 15 & 9 & 15 \\
\hline 70 (long-term effects) & 9 & 15 & 9 & 15 \\
\hline
\end{tabular}

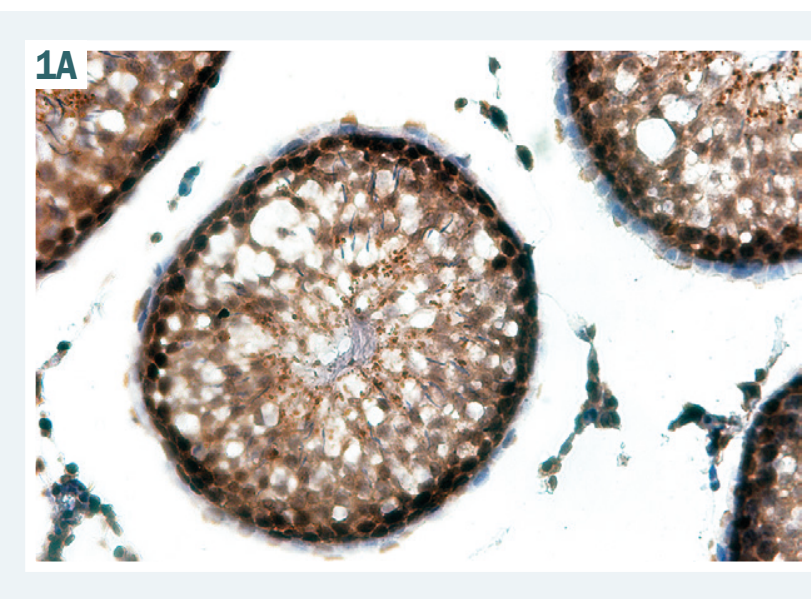

$1 C$

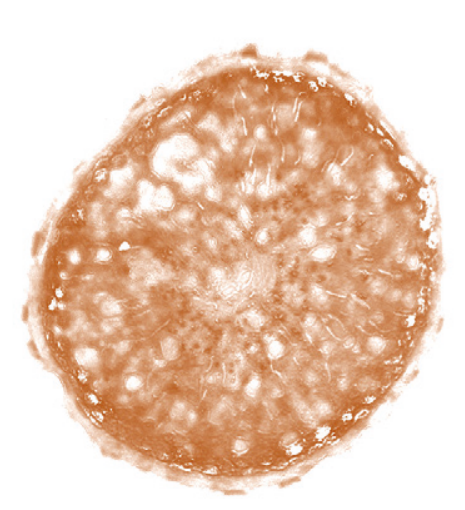

1B

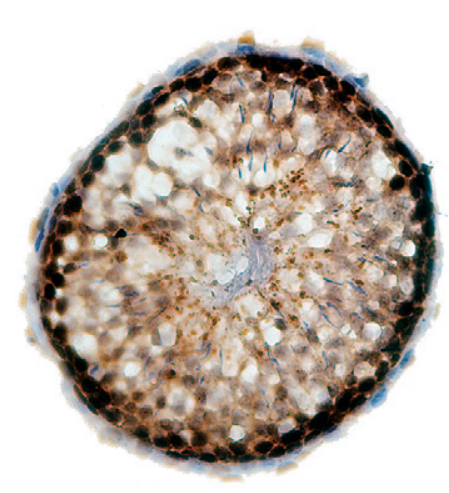

1D

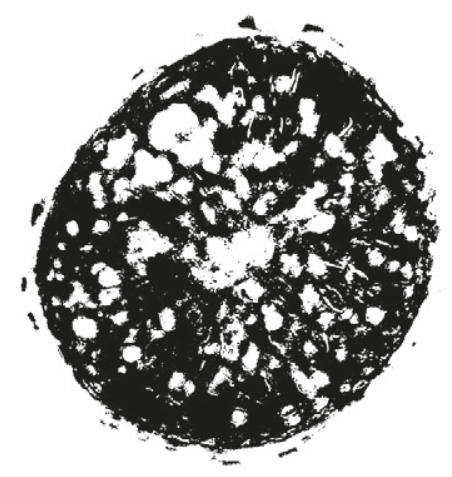

Fig. 1. Mean relative immunoreactive area. A: Nuclear and cytoplasmic AR-immunoreactivity of seminiferous tubule in the peripubertal period (IHC, $\times 400)$. B: Removed all elements except the cut of one tubule. C: After the deconvolution, a photo with a brown mask was chosen. D: Binarization is a necessary step for measuring the area occupied by the pigment.

Morphometric study. Digital photos were obtained from the regions of studied tumors using ZEISS Axiocam 512 color camera under Axio Imager.A2 microscope (magnification $\times 100 / 200 / 400$, depending on the marker). Each sample was illustrated with 3 photos. The area and linear dimensions were measured using the tools of Image J $1.49 \mathrm{v}$ package [6].

Proliferative activity was easily assessed by counting the rows of Ki-67 expressing spermatogonia. Caspase- 3 and $A R$ showed such wide distribution in seminiferous tubules that required the analysis of the immunopositive area share (Fig. 1). WT1 expression enables calculating the mean number of Sertoli cells per tubule. In order to measure the width of the walls in the microvasculature, three indicative cross-cut vessels were chosen in any single case.

Statistical analysis was conducted using Statistica software (version 6.1; serial number AGAR 909 E415822FA). Shapiro-Wilk test was used for checking whether the distribution of the values is normal.

Since the distribution in most parameters was estimated abnormal, Mann-Whitney U test was employed to assess the differences amongst the experimental groups, while Spearman's rank test was suitable for correlative analysis. For the effective presentation of such data, the box and whisker plots were constructed and formatted using the tools of MS Word 2010. P $<0.05$ value was accepted to be statistically significant [7].

\section{Results}

This study examined the short and long term effects of STZ-induced diabetes mellitus on proliferation, apoptosis, microvasculature, expression of androgen receptors in Leydig cells, and the number of Sertoli cells in late puberty and adulthood.

Proliferative activity. Typically, Ki-67 demonstrates diffuse or diffusely focal nuclear staining (Fig. 2A). However, the Ki-67 label was completely focal in weakly stained cells. PI of endothelial cells was very high $(81.9(44.3 ; 90.1) \%)$ in the peripubertal group, indicating ongoing vasculogenesis. The analogous parameter is lower in the adult group but insignificantly (Mann-Whitney test, $P>0.05$ ). Although 

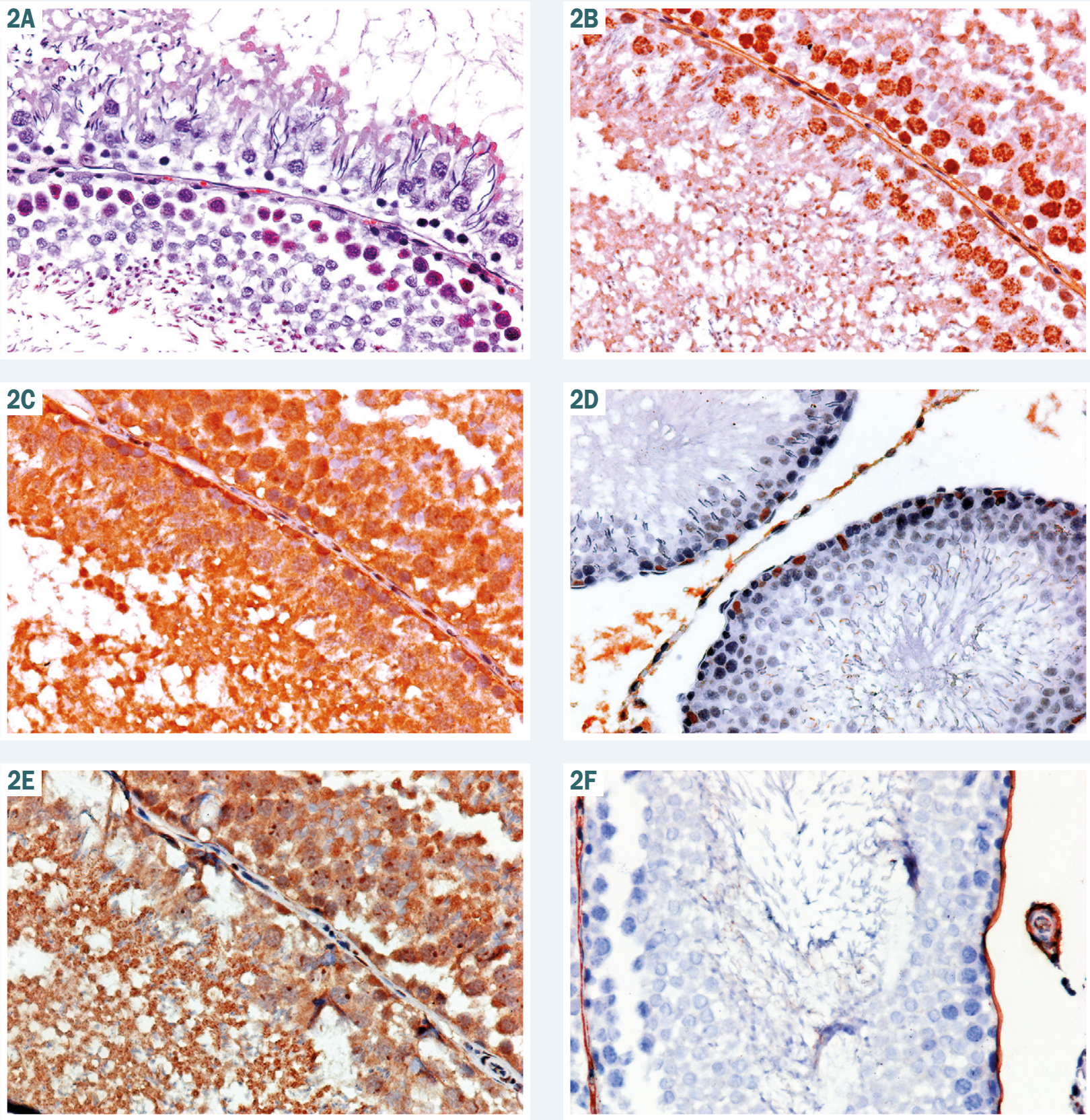

Fig. 2. Seminiferous tubules in adult rats with STZ-induced hyperglycemia ( 8 weeks). A: Subtle degeneration of spermatogenic tissue (H\&E, x400). B: Intensive proliferation (Ki-67) in 2 basal layers of spermatogonia. C: Cytoplasmic caspase-3-immunoreactivity in most cells. D: Relatively rare WT1+ Sertoli cells, weak background reaction in spermatogonia. E: Mostly cytoplasmic IHC reaction (AR) in both sustentocytic and spermatogenic lineages. F: Highlighted by CD34 accumulation, thick vascular walls were measured in areas with artificially incoherent testicular tissue. B-F. IHC, $\times 400$.

the interstitial hormone-producing cells demonstrated a relatively low level of PI $(6.2(3.5 ; 19.7) \%)$ with significantly (Mann-Whitney test, $\mathrm{P}<0.05$ ) higher values in control groups (16.3 (10.6; 54.2) \%), it can be at least partly explained by the more cellular clusters of interstitial cells in the latter group. In terms of seminiferous tubules, we found the distinction between control and experimental groups so vivid, that it was not necessary to calculate PI. Instead, we compared the number of Ki-67-positive rows and proved the differences in both adult and peripubertal rats (Mann-Whitney test, $\mathrm{P}<0.05$ ). The farther details are presented in Fig. $3 A, 4 A$.
Apoptosis. Caspase-3 labels were intracytoplasmic with the tendency for the perinuclear zone, especially in spermatogonia (Fig. 2C). We registered caspase-3 expression in interstitial cells (index of expression 23.7 (14.7; $60.0) \%)$ and in endothelial cells $(45.5(12.1 ; 83.2) \%)$.

Long-term hyperglycemia (Fig. 4B) induced the lower levels of caspase- 3 reactivity of seminiferous tubules at both ages (Mann-Whitney test, $P<0.05$ ). In shortterm groups (Fig. 3B), the drop of the immunoreactive tubular area was found in adult rats (Mann-Whitney test, $P<0.05)$, whereas peripubertal ones retain relatively high levels of labeling (40-50\%). 

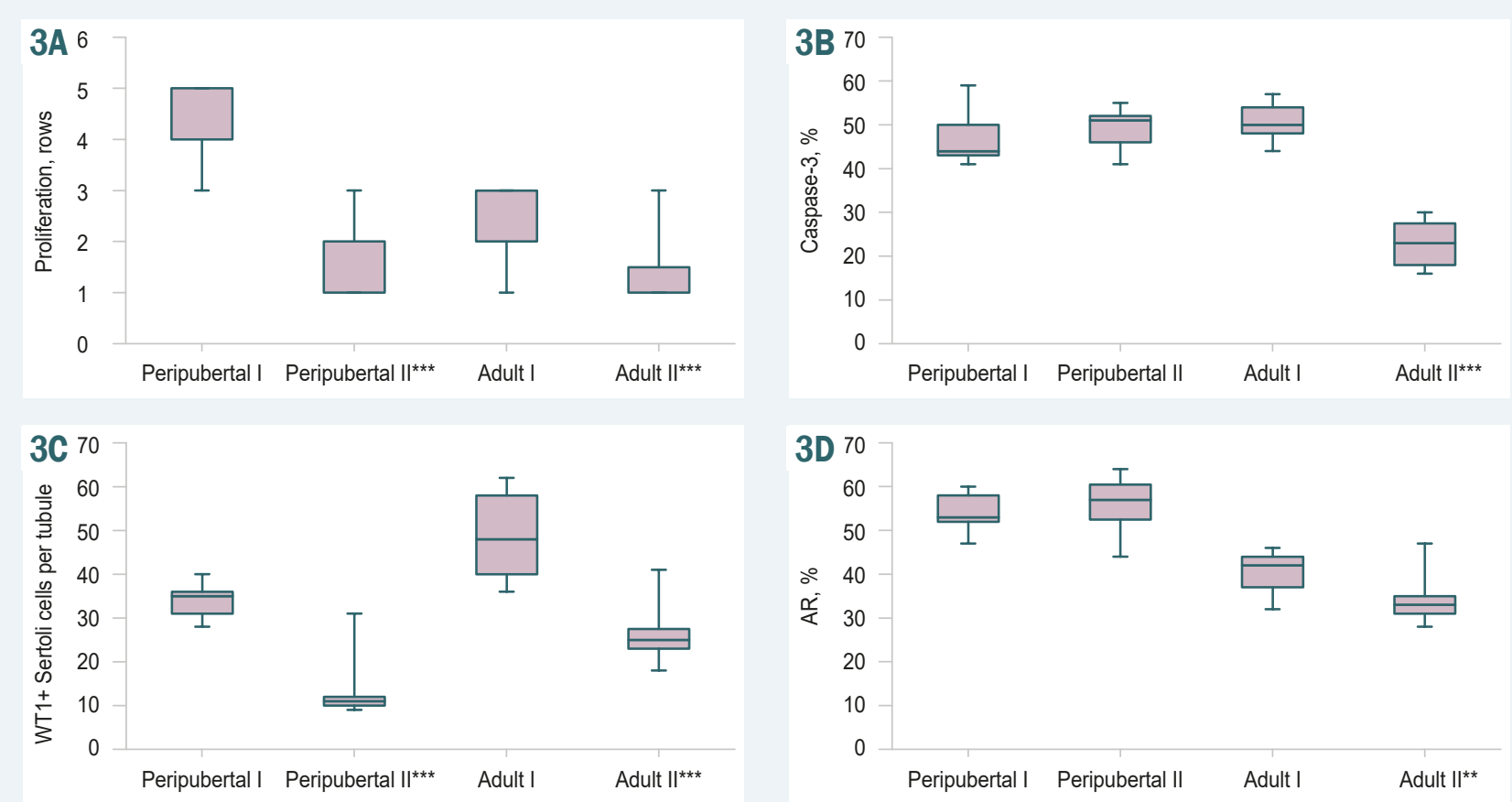

3D 70
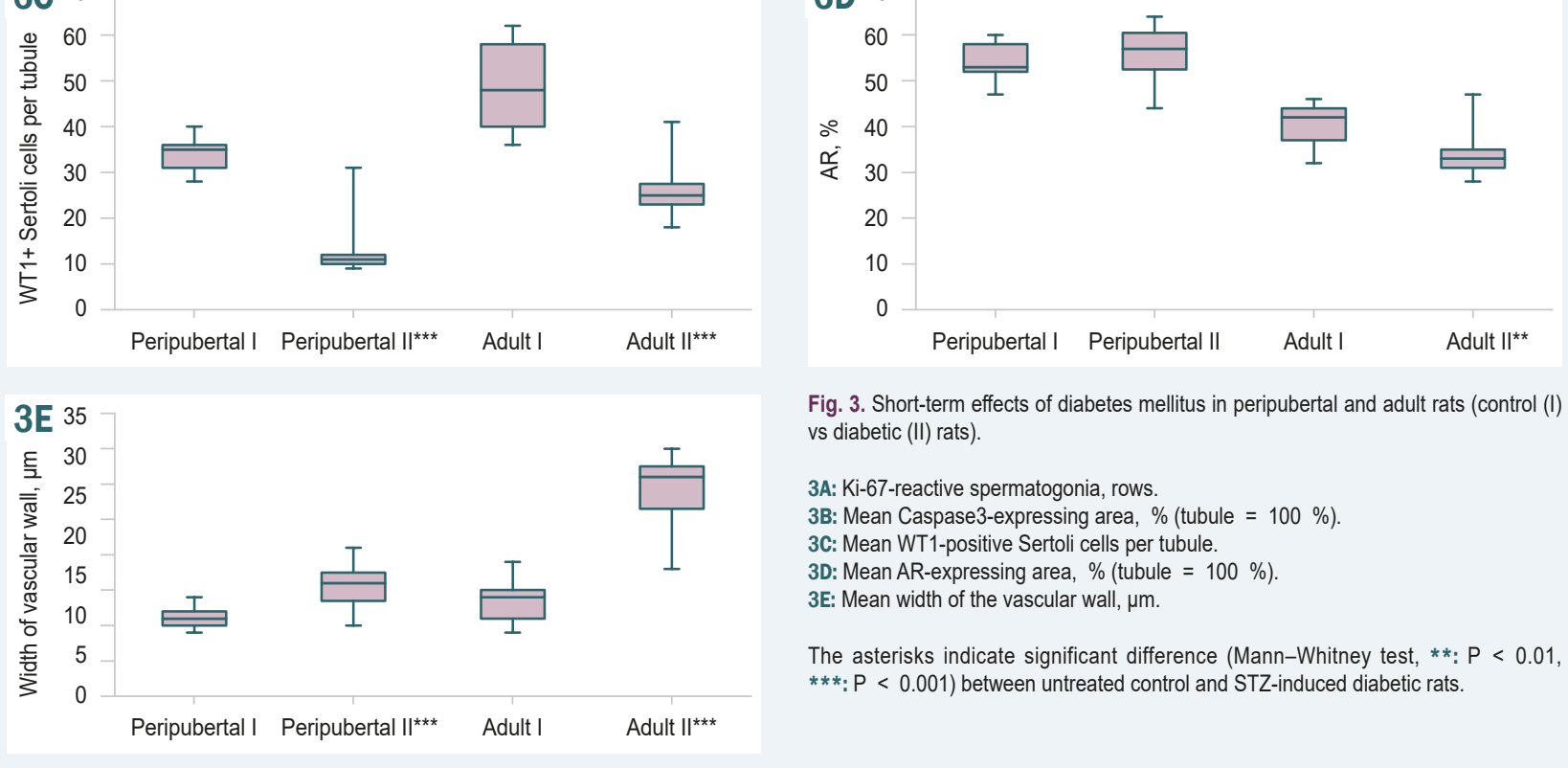

Fig. 3. Short-term effects of diabetes mellitus in peripubertal and adult rats (control (I) vs diabetic (II) rats).

3A: Ki-67-reactive spermatogonia, rows.

3B: Mean Caspase3-expressing area, \% (tubule = $100 \%$ ).

3C: Mean WT1-positive Sertoli cells per tubule.

3D: Mean AR-expressing area, \% (tubule $=100 \%$ ).

3E: Mean width of the vascular wall, $\mu \mathrm{m}$.

The asterisks indicate significant difference (Mann-Whitney test, **: $\mathrm{P}<0.01$ $* * *: P<0.001)$ between untreated control and STZ-induced diabetic rats.

WT1+ Sertoli cells. WT1-immunoreactivity varied in the samples. Sertoli cells demonstrated intensive and moderate nuclear staining, whereas in diabetic groups the Sertoli cells are less numerous (Mann-Whitney test, $P<0.05)$ and the intensity of the reaction is significantly lower (Fig. 2D, 3C and 4C). The results in adult and prepubertal testes were statistically equal (Mann-Whitney test, $P>0.05$ ) in control, but the number of WT1-positive Sertoli cells was lower among younger groups with DM (Mann-Whitney test, $P<0.05$ ).

In addition, in control groups, a few WT1-positive nuclei were detected in the higher layers among maturing germ cells, mostly in the seminiferous tubules in late spermatogenesis. Meanwhile, such sections are not recognized in diabetic groups.

AR. Immunohistochemical study revealed that the nuclei of spermatogenic lineage $(+)$, Leydig cells $(+++)$, Sertoli cells $(+++)$, and peritubular myoid cells $(+++)$ exhibited positive reactivity to anti-AR (Fig. 2E). The expression of AR in germ cells has been controversial. Area of AR-reactivity correlates with the values of caspase-3-immunoreactivity (Spearman's rank test, $r=0.682, P<0.05)$. Consequently, the differences between groups were similar (Fig. 3D, 4D).

Microvascular morphology (CD34-based). CD34-immunolabels enable a precise analysis of the mi- crovasculature (Fig. 2F). The diameter of microvessels (with walls) varied between 0.06 and $0.15 \mathrm{~mm}$. The vascular walls were as thin as $10-40 \mu \mathrm{m}$ (Fig. 3E, 4E). In experimental groups, they were significantly thicker (Mann-Whitney test, $P<0.05$ ).

\section{Discussion}

During mitosis, Ki-67 is essential for the formation of the perichromosomal layer, a ribonucleoprotein sheath coating the condensed chromosomes. In this structure, $\mathrm{Ki}-67$ acts to prevent the aggregation of mitotic chromosomes [8]. In general, the tendency of spermatogenesis arrest corresponds to data published by T. Karaca et al. in their report [9]. However, they did not note the PI for non-spermatogenic cells.

Caspases are a family of proteins essential in the apoptotic mechanism. Upon an apoptotic stimulus, initiator caspases are activated starting the biochemical apoptotic cascade. The initiator caspases- 8 and -9 are responsible for the extrinsic and intrinsic apoptotic pathway activation, respectively, leading to the most important effector caspase activation: caspase-3. Caspase-3 activation marks the point of no return in the apoptotic process and is responsible for key proteins cleavage leading to final cell disassembly [10]. Although we encountered 

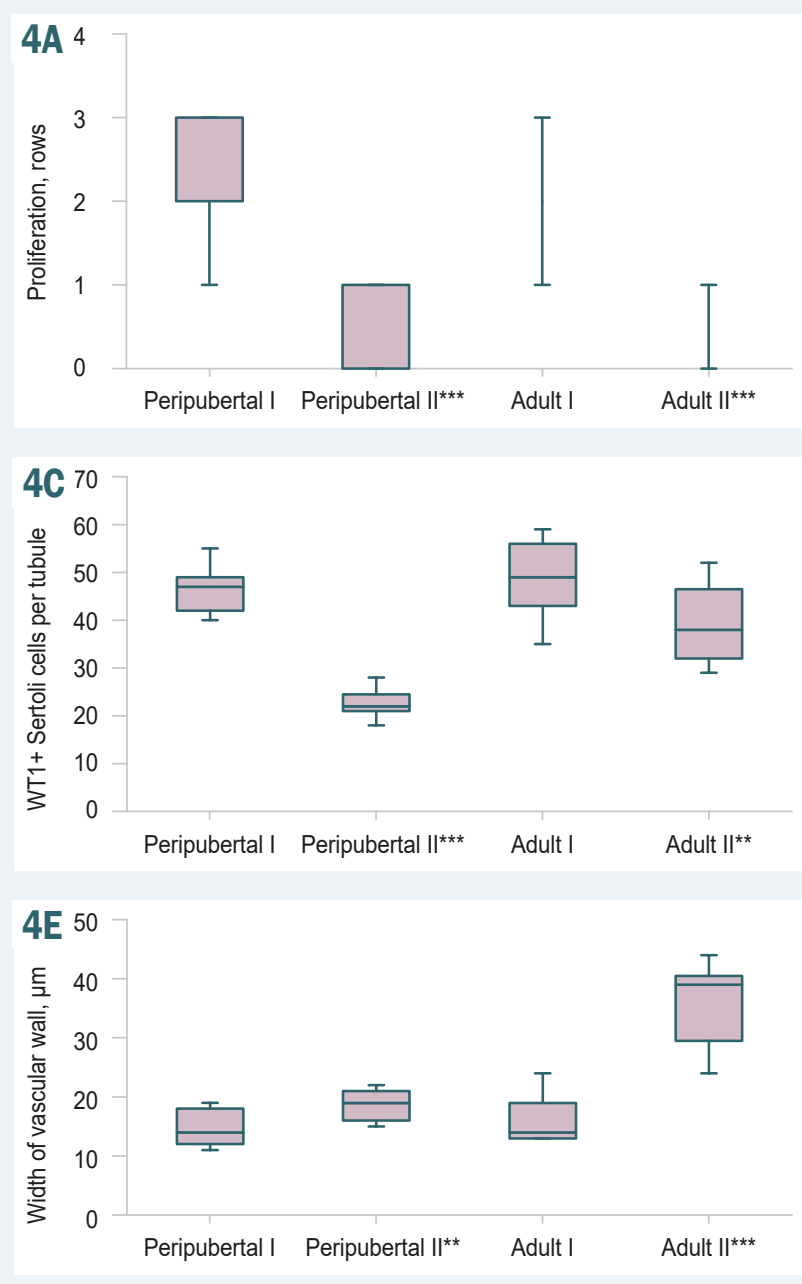
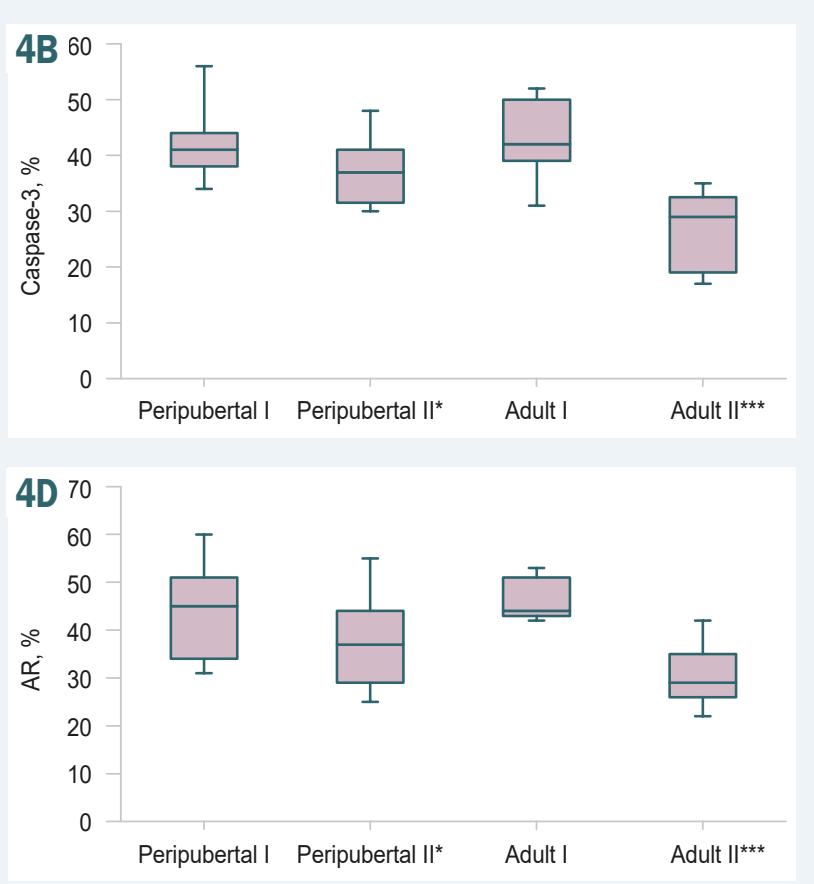

Fig. 4. Long-term effects of diabetes mellitus in peripubertal and adult rats (control (I) vs diabetic (II) rats).

A: Ki-67-reactive spermatogonia, rows.

B: Mean Caspase3-expressing area, \% (tubule = $100 \%$ ).

C: Mean number of WT1-positive Sertoli cells per tubule.

D: Mean AR-expressing area, $\%$ (tubule $=100 \%$ ).

E: Mean width of the vascular wall, $\mu \mathrm{m}$.

The asterisks indicate significant difference (Mann-Whitney test, *: $P<0.05$, $\left.{ }^{* *}: \mathrm{P}<0.01,{ }^{* * *} \mathrm{P}<0.001\right)$ between untreated control and STZ-induced diabetic rats. some works describing nuclear immunostaining [9], they seem to be implausible. In all the publications we have read, the authors report the increased caspase expression in the spermatogenic tissue of diabetic rats. However, they applied other methods of registration, what can partly explain the controversy $[9,11]$. The fact that some cells produce both Ki-67 and caspase-3 appears controversial and requires further investigations.

WT1 is not just known as an immunohistochemical marker of Sertoli cells but also dictates the development and hormonal activity of testicular interstitium [12]. Wang X.N. et al. showed the morphology of WT1-positive Sertoli cells [13]. However, we did not find any papers assessing WT1-immunostaining in STZ-induced diabetes, not to mention the prepubertal rats with this condition. Therefore, the involution and/or pure development of Sertoli cells shown in this work suggest the additional pathway involved in male sexual dysfunction and infertility.

Androgens exert their action through AR and its signaling in the testis is essential for spermatogenesis. $A R$ is not expressed in the developing germ cell lineage so is thought to exert its effects through testicular Sertoli and peri-tubular myoid cells [14]. Some studies claim the presence of $A R$, while other studies deny its appearance. However, both teams agreed that $A R$ has been implicated in the process of gametogenesis $[3,15]$.
Strong evidence demonstrates CD34 is expressed not only by MSC but by a multitude of other nonhematopoietic cell types including muscle satellite cells, corneal keratocytes, interstitial cells, epithelial progenitors, and vascular endothelial progenitors. In many cases, the CD34(+) cells represent a small proportion of the total cell population and also indicate a distinct subset of cells with enhanced progenitor activity [16].

\section{Conclusions}

In conclusion, the diabetic injury of testicular tissue is a long time process requiring long-term experimental observations. Therefore, the complete complex of structural modifications is to be expected in months and, probably, years after the onset of DM, although the functional changes along with the hemodynamic disorders might be obvious even in several days of hyperglycemia. In addition, rats in the peripubertal period are proved to possess characteristic features, for example, the later developing deficiency of $A R(P<0.05$ just in the 10 weeks' group). Also, the high level of apoptosis is characteristic of an immature testis and so is the tendency of caspase-immunoreactivity to persist. Caspase-3 expression, however, drops later $(P<0.05)$ even in the group of reproductively immature rats. 
Funding

The research was performed within the framework of the research work of Ivano-Frankivsk National Medical University "Morphofunctional characteristics of some organs of the nervous, endocrine, digestive and genital systems in diabetes mellitus in conditions of chronic stress" (state registration number 0119U003551).

Conflicts of interest: authors have no conflict of interest to declare. Конфлікт інтересів: віАсутній.

Надійшла Ао редакції / Received: 21.12.2020

Після Аоопрацювання / Revised: 26.02.2021

Прийнято Ао Аруку / Accepted: 09.03.2020

\section{Information about authors:}

Kondrat I.-A. V., PhD student of the Department of Pathological Anatomy, Ivano-Frankivsk National Medical University, Ukraine. ORCID ID: 0000-0003-3284-7057

Shponka I. S., MD, PhD, DSc, First Vice-Rector, Professor of the Department of Pathological Anatomy and Forensic Medicine, Dnipro State Medical University, Ukraine.

ORCID ID: 0000-0002-7561-6489

Shynkarenko T. V., MD, PhD, Assistant Professor of

the Department of Pathological Anatomy and Forensic Medicine, Dnipro State Medical University, Ukraine.

\section{ORCID ID: 0000-0002-3428-7949}

\section{Відомості про авторів:}

Конарат І.-А. В., аспірант каф. патологічної анатомії, ІваноФранківський національний медичний університет, Україна. Шпонька І. С., А-р меА. наук, перший проректор, професор каф. патологічної анатомії і судової медицини, Аніпровський Аержавний медичний університет, Україна.

Шинкаренко Т. В., канА. меА. наук, асистент каф. патологічної анатомії і судової меАицини, Аніпровський Аержавний медичний університет, Україна.

\section{Сведения об авторах:}

Кондрат И.-А. В., аспирант каф. патологической анатомии, Ивано-Франковский национальный меАицинский университет, Украина.

Шпонька И. С., А-р меА. наук, первый проректор, профессор каф. патологической анатомии и судебной меАицины, Анепровский государственный медицинский университет, Украина.

Шинкаренко Т. В., канА. меА. наук, ассистент

каф. патологической анатомии и судебной меАицины, Анепровский государственный медицинский университет, Украина.

\section{References}

[1] Jangir, R. N., \& Jain, G. C. (2014). Diabetes mellitus induced impairment of male reproductive functions: a review. Current diabetes reviews, 10(3), 147-157. https://doi.org/10.2174/1573399810666140606111745

[2] Donmez, Y. B., Kizilay, G., \& Topcu-Tarladacalisir, Y. (2014). MAPK immunoreactivity in streptozotocin-induced diabetic rat testis. Acta cirurgica brasileira, 29(10), 644-650. https://doi.org/10.1590/s01028650201400160004

[3] Trindade, A. A., Simões, A. C., Silva, R. J., Macedo, C. S., \& Spadella, C. T. (2013). Long term evaluation of morphometric and ultrastructural changes of testes of alloxan-induced diabetic rats. Acta cirurgica brasileira, 28(4), 256-265. https://doi.org/10.1590/s0102$\underline{86502013000400005}$

[4] Kanter, M., Aktas, C., \& Erboga, M. (2013). Curcumin attenuates testicular damage, apoptotic germ cell death, and oxidative stress in streptozotocin-induced diabetic rats. Molecular nutrition \& food research, 57(9), 1578-1585. https://doi.org/10.1002/mnfr.201200170

[5] Nna, V. U., Abu Bakar, A. B., Ahmad, A., Eleazu, C. O., \& Mohamed, M. (2019). Oxidative Stress, NF-kB-Mediated Inflammation and Apoptosis in the Testes of Streptozotocin-Induced Diabetic Rats: Combined Protective Effects of Malaysian Propolis and Metformin. Antioxidants, 8(10), 465. https://doi.org/10.3390/antiox8100465
[6] Poslavska, O. V. (2015). Metodolohiia vykorystannia prohramnoho zabezpechennia dlia analizu tsyfrovykh mikrofotohrafii na bazi kursu patomorfolohii z metoiu pidvyshchennia profesiinoho rivnia studentiv i naukovtsiv [Methodology for the use of software for the analysis of digital micrographs on the base of pathomorphology course in order to increase the professional level of students and scientists]. Morphologia. 9(3), 122-126. [in Ukrainian]. https://doi.org/10.26641/1997$9665.2015 .3 .122-126$

[7] Antomonov, M. Yu. (2006). Matematicheskaya obrobotka i analiz mediko-biologicheskikh dannykh [Mathematical processing and analysis of biomedical data]. Kiev: Firma Maliy Druk. [in Russian].

[8] Sun, X., \& Kaufman, P. D. (2018). Ki-67: more than a proliferation marker. Chromosoma, 127(2), 175-186. https://doi.org/10.1007/ s00412-018-0659-8

[9] Karaca, T., Demirtaş, S., Karaboğa, I., \& Ayvazz, S. (2015). Protective effects of royal jelly against testicular damage in streptozotocin-induced diabetic rats. Turkish journal of medical sciences, 45(1), 27-32.

[10] Chowdhury, I., Tharakan, B., \& Bhat, G. K. (2008). Caspases - an update. Comparative biochemistry and physiology. Part B, Biochemistry \& molecular biology, 151(1), 10-27. https://doi.org/10.1016/j. cbpb.2008.05.010

[11] Khosravi, Z., Sedaghat, R., Baluchnejadmojarad, T., \& Roghani, M. (2019). Diosgenin ameliorates testicular damage in streptozotocindiabetic rats through attenuation of apoptosis, oxidative stress, and inflammation. International immunopharmacology, 70, 37-46. https:// doi.org/10.1016/i.intimp.2019.01.047

[12] Wen, Q., Zheng, Q. S., Li, X. X., Hu, Z. Y., Gao, F., Cheng, C. Y., \& Liu, Y. X. (2014). Wt1 dictates the fate of fetal and adult Leydig cells during development in the mouse testis. American journal of physiology. Endocrinology and metabolism, 307(12), E1131-E1143. https://doi. org/10.1152/ajpendo.00425.2014

[13] Wang, X. N., Li, Z. S., Ren, Y., Jiang, T., Wang, Y. Q., Chen, M., Zhang, J., Hao, J. X., Wang, Y. B., Sha, R. N., Huang, Y., Liu, X., Hu, J. C., Sun, G. Q., Li, H. G., Xiong, C. L., Xie, J., Jiang, Z. M., Cai, Z. M., Wang, J., ... Gao, F. (2013). The Wilms tumor gene, Wt1, is critical for mouse spermatogenesis via regulation of sertoli cell polarity and is associated with non-obstructive azoospermia in humans. PLOS genetics, 9(8), e1003645. https://doi.org/10.1371/journal.pgen.1003645

[14] O'Hara, L., \& Smith, L. B. (2015). Androgen receptor roles in spermatogenesis and infertility. Best practice \& research. Clinical endocrinology \& metabolism, 29(4), 595-605. https://doi.org/10.1016/j. beem.2015.04.006

[15] Abd El-Meseeh, N. A., El-Shaarawy, E. A., AIDomairy, A. F., \& Sehly, R. A. (2016). Changes in rat testis morphology and androgen receptor expression around the age of puberty. Annals of anatomy, 205, 37-44. https://doi.org/10.1016/j.aanat.2016.01.003

[16] Sidney, L. E., Branch, M. J., Dunphy, S. E., Dua, H. S., \& Hopkinson, A. (2014). Concise review: evidence for CD34 as a common marker for diverse progenitors. Stem cells, 32(6), 1380-1389. https:// doi.org/10.1002/stem.1661 